Ann. Biol. anim. Bioch. Biophys., 1978, 18 (4), 1035-1043.

\title{
The effects of alterations in photoperiod on ovarian development and spawning time in the rainbow trout (Salmo gairdneri)
}

\author{
par C. WHITEHEAD, N. R. BROMAGE (1), J. R. M. FORSTER *, A. J. MATTY \\ With the technical assistance of J. RALPH *, Susan TAYLOR. \\ Fish Culture Unit, Department of Biological Sciences, \\ University of Aston in Birmingham B4 7ET, U.K. \\ * Shearwater Fish Farming Lid., Armathwaite, \\ Nr. Carlisle, Cumbria, CA4 9TT, U. K.
}

\begin{abstract}
Summary. The present study investigates the changes in serum œstradiol $17 \beta$, total calcium and phosphoprotein (as a measure of vitellogenesis) under a normal seasonal 12 month photoperiod cycle, normal yearly cycles compressed into 9 and 6 months, and a constant 12 hour light/ 12 hour dark regime and the effects of these experimental photoperiod regimes on the times of spawning of both male and female rainbow trout.

Spawning was advanced by 6 weeks under the 9 months photoperiod regime, and by 12 weeks under the 6 month regime in comparison with the normal cycle. The levels of œstradiol $17 \beta$, calcium and phosphoprotein demonstrated under the simulated normal yearly cycle were markedly altered in female fish under the other photoperiod regimes and in each case coincided with the alterations in spawning time, thus indicating the involvement of these materials in the control of the processes of vitellogenesis and spawning.

These results indicate that photoperiod is the major environmental factor in the control of the sequence of endocrine and other physiological changes which ultimately lead to spawning in salmonids and suggest that photoperiod may act by modifying an inherent reproductive rhythm.
\end{abstract}

\section{Introduction.}

In seasonally-breeding fish many factors from both the external and internal environments are thought to act as cues for the initiation of the complex series of neuroendocrine changes which exert overall control of the processes of gonadal maturation and spawning. Amongst the large number of factors reported in the literature, photoperiod and temperature are the most frequently mentioned (see de Vlaming, 1972) although the relative importance of each factor varies with different species of fish. Previous work suggests that photoperiod exerts the major controlling influence in salmonids (Alison, 1951 ; Hazard and Eddy, 1951 ; Nomura, 1962 ; Henderson, 1963 ; Carlson and Hale, 1973 ; Kunesh et al., 1974) although in some of these studies other environmental factors besides photoperiod varied during the course of the experiments.

(1) Any communication regarding this paper should be addressed to : Dr. N. R. Bromage. 
Additionally, apart from Sundararaj and Sehgal (1970) with catfish and Breton and Billard (1977) and Whitehead ef al. $(1977 a, 1977 b)$ with rainbow trout, few workers have studied the various physiological and endocrine changes which occur in response to these environmental triggers, and which initiate and control the onset and course of maturation and spawning.

In view of these difficulties the present work, whilst maintaining close control of all other environmental variables, investigates firstly the effect of various photoperiod regimes on spawning in the rainbow trout and, secondly, the dynamic changes in serum levels of oestradiol $17 \beta$, calcium and phosphoprotein (as a measure of vitellogenesis) which accompany this process.

\section{Materials and methods.}

Four groups of 20 immature, 2-year old, male and female rainbow trout (Salmo gairdneri), each weighing approximately $1.3 \mathrm{~kg}$, were maintained in light-proof aquaria and exposed to four different photoperiod regimes provided by fluorescent light and controlled by electric time clocks adjusted once per week. The 4 photoperiod regimes under investigation (shown in fig. 1) were as follows :

1. Normal 1 year seasonal cycle (control) in which July 4th was the longest day and December 20th the shortest.

2. Normal seasonal cycle compressed into 9 months in which June 4 th was the longest day and October 20th the shortest.

3. Normal seasonal cycle compressed into 6 months in which May 4th was the longest day and August 8 th the shortest.

4. Constant $12 \mathrm{hr}$ light/12 hr dark regime.

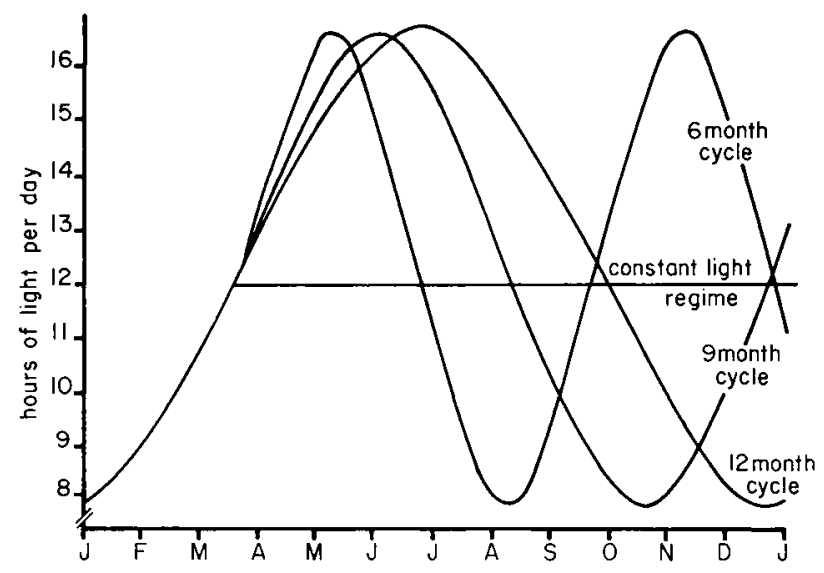

FIG. 1, - Photoperiod regimes under investigation.

In all groups, experimental conditions were closely controlled; water from a borehole supply was maintained at $9 \circ \mathrm{C}$ throughout the experiment, with a constant flow rate, a dissolved oxygen content of 100 p. 100 in the effluent, and a $\mathrm{pH}$ of 6.6. 
The fish were fed on a proprietary diet at 0.5 p. 100 of the body weight per day. Blood samples were withdrawn from 10 fish in each group, via the Cuverian vein, in March at the start of the experiment and each month thereafter. The number of female fish in each group varied as indicated in tables 1-4. The serum thus obtained was assayed for oestradiol $17 \beta$, total calcium and phosphoprotein by the following methods :

1. Oestradiol $17 \beta$ was assayed by radioimmunoassay using a modification of the method of Leonard and Craig (1974) in which a serum sample of only $200 \mu$ was used and in the extraction phase the sample was brought within the correct standard range by taking a $500 \mu \mathrm{l}$ aliquot of the original $5 \mathrm{ml}$ extractant. The standard curve on all occasions exhibited full parallelism with dilutions of rainbow trout sera. The cross-reactivity of the antisera was 10 p. 100 with oestriol, 3 p. 100 oestrone and 1 p. 100 with testosterone relative to oestradiol.

2. Total serum calcium was assayed by a fluorimetric method using a Corning calcium analyser model 940.

3. Serum phosphoprotein was assayed by measurement of its phosphorus content (Boehringer Corporation Test Handbook, 1969) with the following modifications : A $100 \mu \mathrm{l}$ serum sample was taken and the proteins precipitated with $5 \mathrm{ml}$ trichloroacetic acid. The precipitate was isolated, washed successively with a series of organic solvents to remove lipid (Wallace and Jared, 1968) and the resultant protein pellet dried and assayed for phosphoprotein phosphorus. These levels may be converted to vitellogenin by multiplying 71.4, assuming that fish, like other vertebrates investigated have 1.4 p. 100 of their vitellogenin as phosphoprotein phosphorus.

\section{Results.}

The various photoperiod regimes produced no adverse physiological or behavioural changes in the experimental fish and, apart from variations in spawning time, they were indistinguishable from fish of the same age maintained in outside ponds under natural environmental conditions. The eggs obtained from each group were fertilized by hand-stripping and showed normal development. Egg size was uniform, irrespective of spawning time $(4.7 \pm 0.2 \mathrm{~mm})$, and there were no differences in fecundity (2000 eggs $/ \mathrm{kg}$ body weight). In all groups the egg survival up to hatching was 75-80 p. 100. Food conversion was stable between 1.3 and 1.6 until the fish were in spawning condition, at which time a slowing down of feeding occurred and preliminary data also suggests an associated loss of conversion efficiency.

As maturation proceeded, gross changes were seen in the serum levels of oestradiol $17 \beta$, phosphoprotein and calcium in all female fish, although the onset and duration of these changes was affected in different ways by each of the four photoperiod regimes. All fish, irrespective of sex or treatment, had similar resting or basal levels of total calcium (12 $\pm 2 \mathrm{mg}$ p. 100 , i. e. mean \pm standard error of the mean) and phosphoprotein phosphorous $(25 \pm 7 \mu \mathrm{g} / \mathrm{ml})$ during the months April to July and oestradiol $17 \beta(130 \pm 15 \mathrm{pg} / \mathrm{ml})$ in April and May. 


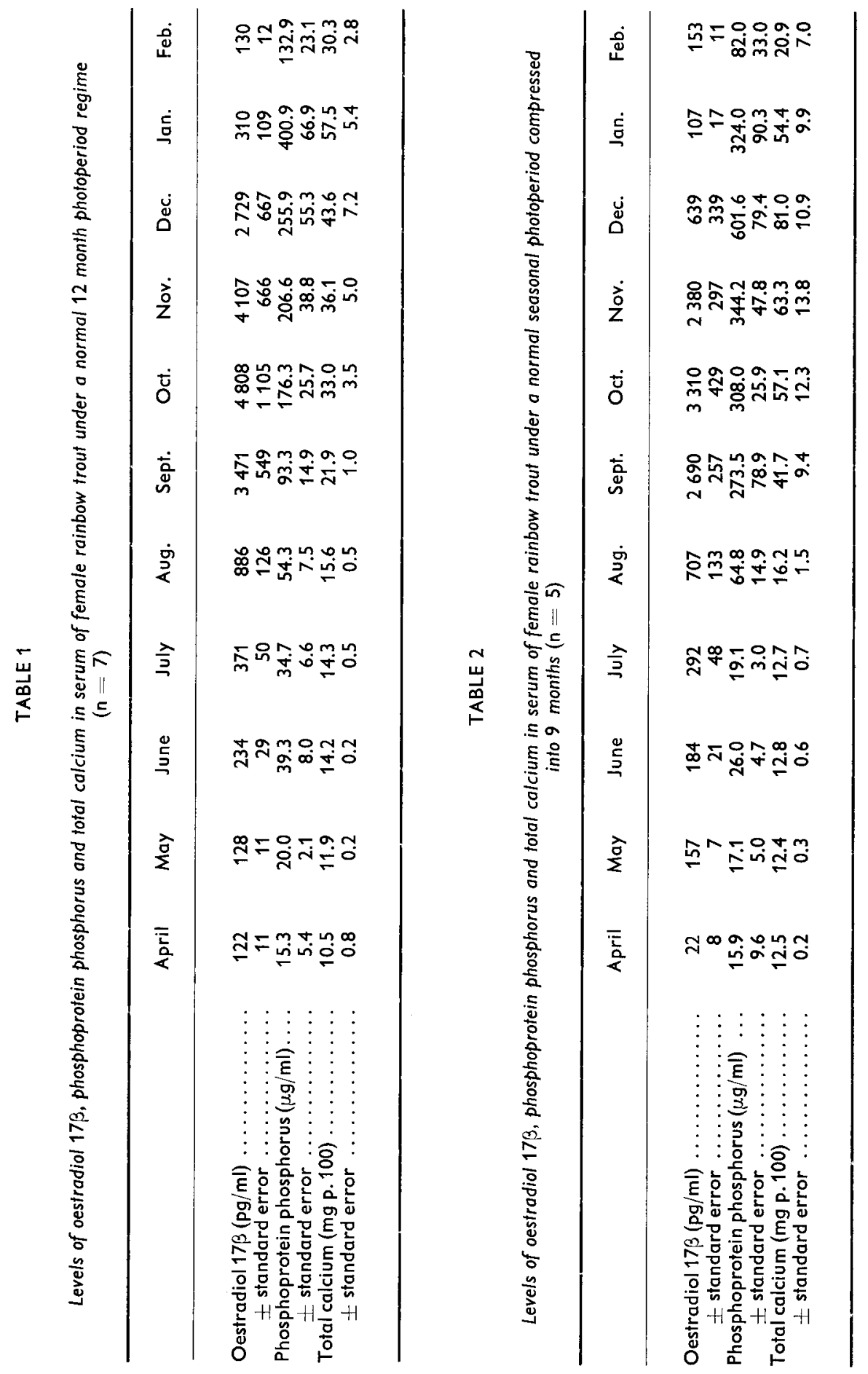


Although the time of ripening and spawning of the male fish under each of the photoperiod regimes occurred at the same time as the female fish in each of the four experimental groups, the serum oestradiol 17 $\beta$, phosphoprotein phosphorous and total calcium remained at basal level throughout the experiment, irrespective of the photoperiod regime. The changes in the female fish induced by the various light regimes are described in more detail below.

1. Normal 1 year seasonal cycle (see table 1). - The fish in this group spawned in mid-January at exactly the same time as broodstock maintained outside in open ponds. Between June and July, serum oestradiol $17 \beta$ levels increased in the female fish from basal levels to a peak of $4800 \pm 1000 \mathrm{pg} / \mathrm{ml}$ in October and then returned to resting levels before the onset of spawning in mid-January (fig. 2). By October the

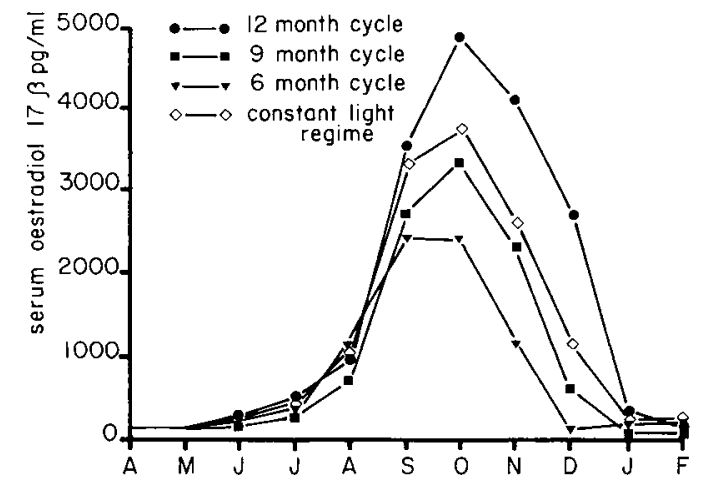

FIG. 2. - Sequential changes in serum oestradiol $17 \beta$ under a normal 12 month photoperiod, normal cycles compressed into 9 and 6 months, and a constant 12-hr light/12 hr dark regime.

serum levels of phosphoprotein phosphorous and calcium of female fish had both begun to rise, reaching peaks of $400 \pm 60 \mathrm{pg} / \mathrm{ml}$ and $58 \pm 10 \mathrm{mg} \mathrm{p.} 100$ respectively in January (figs. 3 and 4).

2. Normal seasonal cycle compressed into 9 months (see table 2). - Spawning in this group occurred in early December, 6 weeks earlier than fish from either the control pholoperiod or the outside ponds. Between June and July serum levels of oestradiol $17 \beta$ in the female fish started to increase, reaching a peak of $3300 \pm 400$ $\mathrm{pg} / \mathrm{ml}$ in October, before returning to resting levels just prior to spawning in early December (fig. 2). Serum levels of phosphoprotein phosphorous and calcium in the female fish were both increased in August, reaching peaks of $600 \pm 80 \mu \mathrm{g} / \mathrm{ml}$ and $80 \pm 20 \mathrm{mg}$ p. 100 respectively, just prior to spawning (figs. 3 and 4).

3. Normal seasonal cycle compressed into 6 months (see table 3). - In this group, spawning occurred in mid-October, approximately 3 months earlier than fish from either the control photoperiod or the outside ponds. Serum levels of oestradiol $17 \beta$ in the females started to increase in July, reaching a peak of $2500 \pm 500 \mathrm{pg} / \mathrm{ml}$ in late September, but returning to basal levels in December (fig. 2). By August, levels 
of serum phosphoprotein phosphorous and total calcium had significantly increased, reaching peaks of $680 \pm 70 \mu \mathrm{g} / \mathrm{ml}$ and $88 \pm 10 \mathrm{mg} \mathrm{p} .100$ respectively in October just before spawning (figs. 3 and 4).

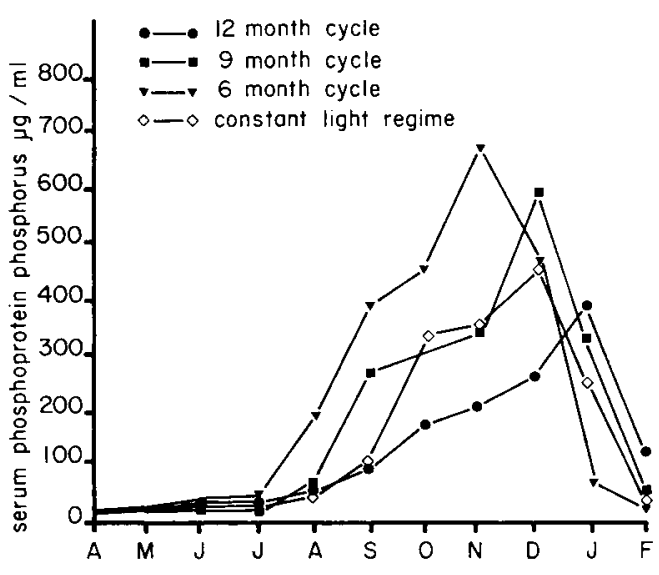

FIG. 3.

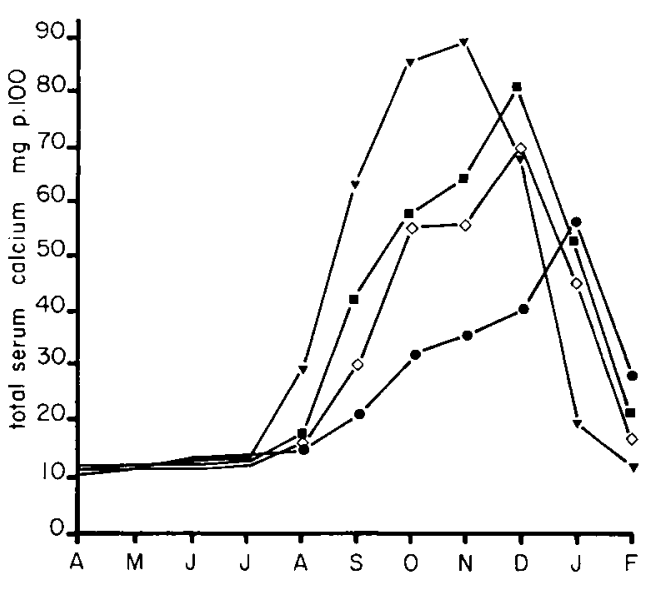

FIG. 4.

FIG. 3. - Sequential changes in serum phosphoprotein phosphorus under a normal 12 month photoperiod, normal cycles compressed into 9 and 6 months, and a constant $12 \mathrm{hr}$ light/12 hr dark regime.

FIG. 4. - Sequential changes in total serum calcium under a normal 12 month photoperiod, normal cycles compressed into 9 and 6 months, and a constant $12 \mathrm{hr}$ light/12 hr dark regime.

4. Constant $12 \mathrm{hr}$ light/12 hr dark regime (see table 4). - Spawning in this group occurred in January at approximately the same time as the control group. Serum levels of oestradiol $17 \beta$ in the females started to increase in July, reaching a peak of $3800 \pm 820 \mathrm{pg} / \mathrm{ml}$ in October before refurning to basal levels in January, at which time spawning occurred (fig. 2). Both serum phosphoprotein phosphorous and total calcium, began to increase during August up to peaks of $480 \pm 60 \mu \mathrm{g} / \mathrm{ml}$ and $70 \pm 14$ mg p. 100 respectively in December, just before the onset of spawning (figs. 3 and 4).

\section{Discussion.}

The present study demonstrates clearly that, in the rainbow trout, photoperiod plays a major role in the initiation of the series of changes in reproductive function which ultimately leads to spawning.

Under the influence of shortened photoperiod, spawning was advanced by 6 and 12 weeks in regimes where the normal yearly cycle was compressed into 9 and 6 months respectively. In both groups early spawning was accompanied by modifications of the normal sequential cycle of serum oestradiol $17 \beta$, calcium and phosphoprotein. Under each of the experimental regimes these changes appeared to be initiated by the decreasing phase of the light regimes which occurred after the longest day. The normal sequential changes in serum oestradiol $17 \beta$, calcium and vitelloge- 


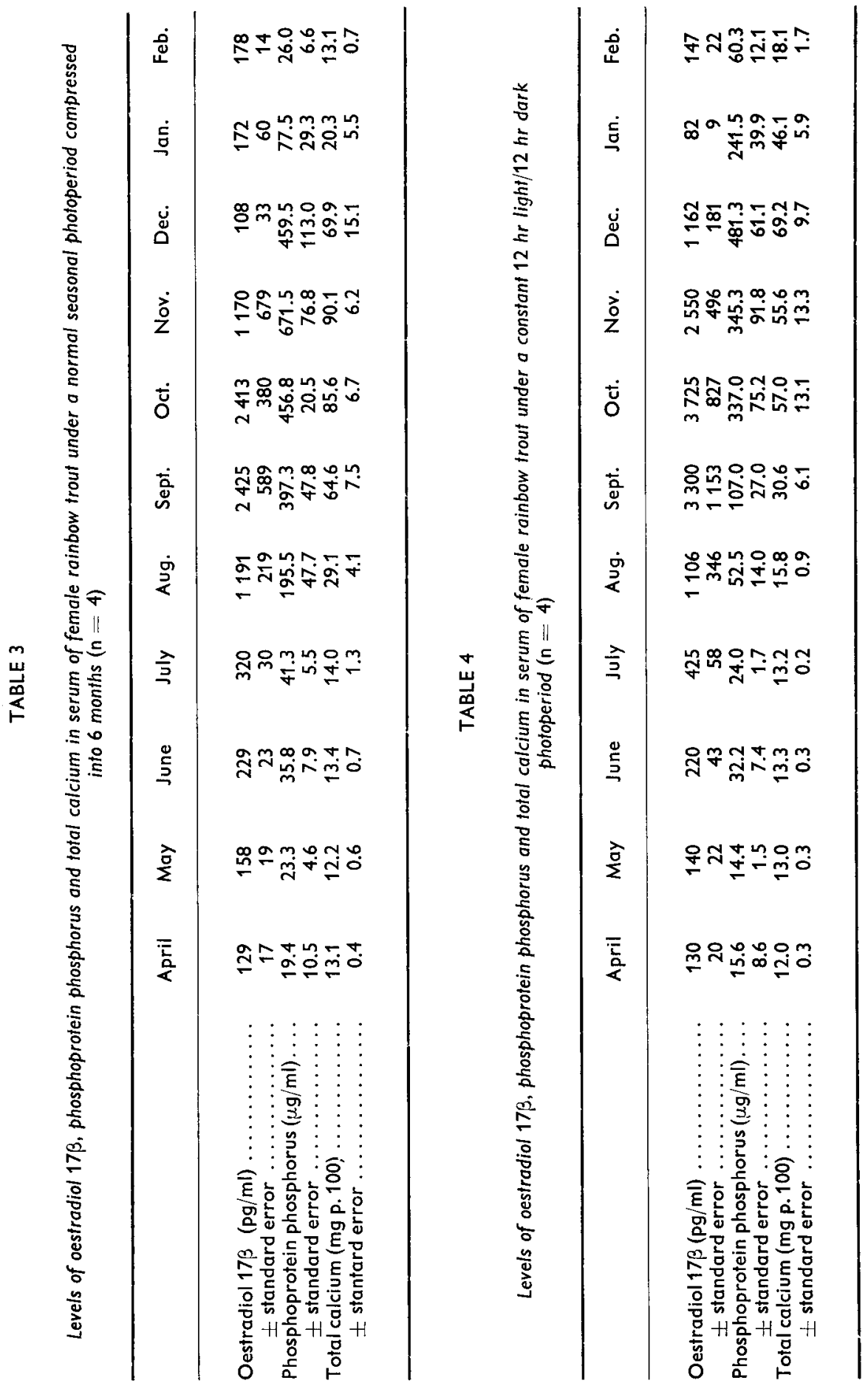


nin seen in fish under natural conditions (Whitehead et al., 1977a) were altered significantly by shortened light regimes and under both regimes the serum levels of oestradiol $17 \beta$, total calcium and phosphoprotein reached peaks before the onset of spawning with the oestradiol refurning to basal levels before ovulation. Since fish, like amphibians and birds, deposit large quantities of yolk in their ova, it is probable that the changes in oestrogen, the hypercalcaemia and increased phosphoprotein production are functionally inter-related. The sequence of events suggests that the control of vitellogenesis in female teleosts is similar to that already demonstrated in amphibians (Wallace and Bergink, 1974 ; Wallace and Jared, 1968). Similar changes have also been observed in the cod (Plack ef al., 1971). Furthermore, the rates of increase of serum calcium and phosphoprotein and the levels achieved before spawning were far greater in the groups under the 6 and 9 months photoperiod regimes than in the controls, probably reflecting an increased rate of vitellogenesis in preparation for early spawning in these groups.

Under the constant light and dark regime the changes in serum components, and spawning, occurred just before those under the normal yearly cycle apparently in the absence of a cue from decreasing photoperiod. This suggests that rainbow trout like many other seasonally-breeding vertebrates may have an endogenous rhythm of reproductive function, which is modified under the influence of photoperiod. This aspect could be further investigated in experiments using constant light regimes of different photoperiod length.

Although the measurements of gonadotropins are not reported here results of a collaborative research programme with Breton and Billard (unpublished) indicate that there are progressive increases in levels of serum gonadotropin during oocyte maturation and vitellogenesis which fall to basal values before the occurrence of a much higher spike of activity just before spawning. This preliminary data on gonadotropins together with the results of the present study clearly supports the hypothesis of a photoperiod control of reproduction by the pituitary probably via the hypothalamus with a subsequent induction by gonadotropic hormone of release of steroids from the gonad.

Symposium sur la Reproduction des Poissons Paimpont, France, 19-21 septembre 1977.

Acknowledgements. - The authors are grateful to the British Oxygen Company for facilities at BOC Shearwater, to Dr. Clive Craik for his suggestions on the modification of the phosphoprotein assay and to the Interdisciplinary Higher Degrees Scheme at Aston for an IHD award to one of us (C. Whitehead).

Résumé. Cette étude porte sur les variations des taux sériques d'estradiol 17 $\beta$, du calcium total et des phosphoprotéines (comme mesure de la vitellogenèse) durant un cycle photopériodique normal de 12 mois, des cycles annuels normaux compressés en 9 et 6 mois et un régime constant de 12 heures de lumière/12 heures d'obscurité. Les effets de ces régimes photopériodiques expérimentaux sont appréciés par les époques de reproduction des truites Arc-en-ciel mâles et femelles.

L'époque de reproduction est avancée de 6 semaines sous le régime photopériodique de 9 mois et de 12 semaines sous celui de 6 mois par rapport au cycle normal. Les niveaux d'estradiol $17 \beta$, calcium et phosphoprotéines observés sous le cycle annuel normal simulé 
sont fortement modifiés chez les femelles soumises aux autres régimes photopériodiques et coïncident dans chaque cas avec les modifications de l'époque de reproduction, ce qui montre que ces composants sont impliqués dans le contrôle des processus de vitellogenèse et de fraie.

Ces résultats indiquent que la photopériode est le principal facteur de l'environnement impliqué dans le contrôle de la séquence des variations endocriniennes et physiologiques qui conduisent finalement à la reproduction des salmonidés et suggèrent que la photopériode peut agir en modifiant un rythme de reproduction inhérent.

\section{References}

ALISON L. N., 1951. Delay of spawning of eastern brook trout by means of artifically prolonged light intervals. Progr. Fish. Cult., 13, 111-116.

BRETON B., BILLARD R., 1977. Effects of photoperiod and temperature on plasma gonadotropin and spermatogenesis in the rainbow trout, Salmo gairdneri Richardson. Ann. Biol. anim. Bioch. Biophys., 17, 1-10.

CARLSON A. R., HALE J. G., 1973. Early maturation of brook trout in the laboratory. Progr. Fish. Cult., 35, 150-153.

DE VLAMING V. L., 1972. Environmental control of teleost reproductive cycles : a brief review. J. Fish Biol., 4, 131-140.

HAZARD T. P., EDDY R. E., 1951. Modification of the sexual cycle in brook trout (Salvelinus fontinalis) by control of light. Trans. am. Fish. Soc., 80, 158-162.

HENDERSON N. E., 1963. Influence of light and temperature on the reproductive cycle of the eastern brook trout, Salvelinus fontinalis (Mitchell). J. Fish. Res. Bd. Can., 20, 859-897.

KUNESH W. H., FRESHMAN W. J., HOEHM M., NORDIN N. G., 1974. Altering the spawning cycle of rainbow trout by control of artificial light. Progr. Fish Cult., 36, 225-226.

LEONARD P. J., CRAIG A., 1974. Non-pregnancy oestrogens, I-44. In CURRY A. S., HEWIT J. V., Biochemistry of women. Methods for clinical investigation, C.R.C. Press, Cleveland, Ohio, USA.

NOMURA M., 1962. Studies on reproduction of rainbow trout Salmo gairdneri, with special reference to egg taking. 3. Acceleration of spawning by control of light. Bull. jop. Soc. scient. Fish., 28, 1070-1076.

PLACK P. A., PRITCHARD D. J., FRAZER N. W., 1971. Egg proteins in cod serum. Biochem. J., 121, 847-856.

SUNDARARAJ B. I., SEHGAL A., 1970. Responses of the pituitary and ovary of the catfish, Heferopneustes fossilis (Bloch) to accelerated light regimen of a decreasing followed by an increasing photoperiod during the postspawning period. Biol. Reprod., 2, 435-443.

WALLACE R. A., JARED D. W. 1968. Studies on amphibian yolk. VII. Serum phosphoprotein synthesis by vitellogenic females and oestrogen treated males of Xenopus laevis. Can. J. Biochem., 46, 953-959.

WALLACE R. A., BERGINK E. W., 1974. Amphibian vitellogenin : properties, hormonal regulation of hepatic synthesis and ovarian uptake, and conversion to yolk proteins. Amer. Zool., 14, 1159-1175.

WHITEHEAD C., BROMAGE N. R., FORSTER, J. R. M., 1977a. Seasonal changes in reproductive hormones of the rainbow trout (Abstr.). Fish. Soc. Brit. Isles Symposium, 4-8 July. Stirling Univ., U.K.

WHITEHEAD C., BROMAGE N. R., FORSTER J. R. M., 1977b. Seasonal changes in reproductive function of the rainbow trout (Solmo gairdneri). J. Fish. Biol. (in press). 